\title{
O pensamento de
}

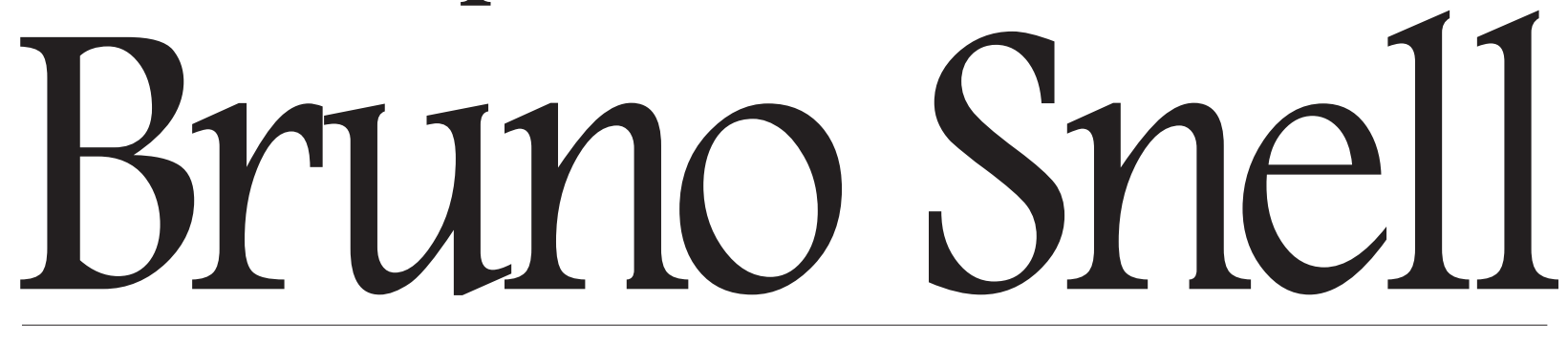

DONALDO SCHÜLER

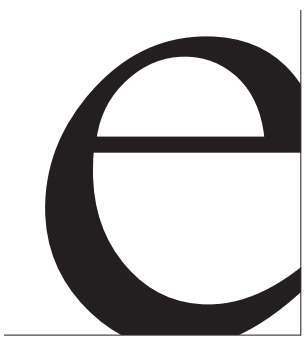

sta não é a primeira tradução da obra de Snell em língua portuguesa. Houve outra com o título A Descoberta do Espírito (Lisboa, Edições 70, 1992). O título brasileiro, A Cultura Grega e as Origens do Pensamento Europeu, aproxima Snell a preocupações correntes. Pensamos, entretanto, que se afasta das intenções do autor. Die Endeckung des Geistes implica o esforço de investigar a fonte psíquica do texto. O livro de Snell aproxima-se, desde o título, do mentalismo de Ingarden, teorizado em A Obra de Arte Literária. Discutível é a busca do "espírito" fora do texto. O que se diz do "espírito" não é antes construção verbal que não desvenda o que fica além? Nesse caso, deveríamos pensar em invenção e não em descoberta. Questionável é também o deter-

DONALDO SCHÜLER é professor de Literatura Grega da UFRGS e tradutor de Finnegans Wake/Finnicius Revém (Ateliê Editorial).

\section{A Cultura Grega e as} Origens do Pensamento Europeu, de Bruno Snell, São Paulo, Perspectiva, 2001. minismo evolucionista de Snell. Em mais de um passo o autor procede como se o o pensamento grego tivesse predeterminado o pensamento europeu. Havendo predeterminação, como esquecer a vertente hebraica, fortíssima nos últimos dois milênios de civilização ocidental? O esforço de síntese desencadeado na Idade Média afe- tou todos os conceitos gregos, o que levou investigadores recentes à tarefa de limpar concepções gregas de contágio judaicocristão. É claro que recuperar o que os gregos realmente pensaram é impossível. Mas um diálogo proveitoso com autores helênicos é prejudicado quando os examinamos por um viés que lhes foi estranho. Traduzir psykhe por alma (Seele) é problemático. Somos tomados de desconforto quando se afirma que autores gregos ainda não alcançaram o que "nós" enten-

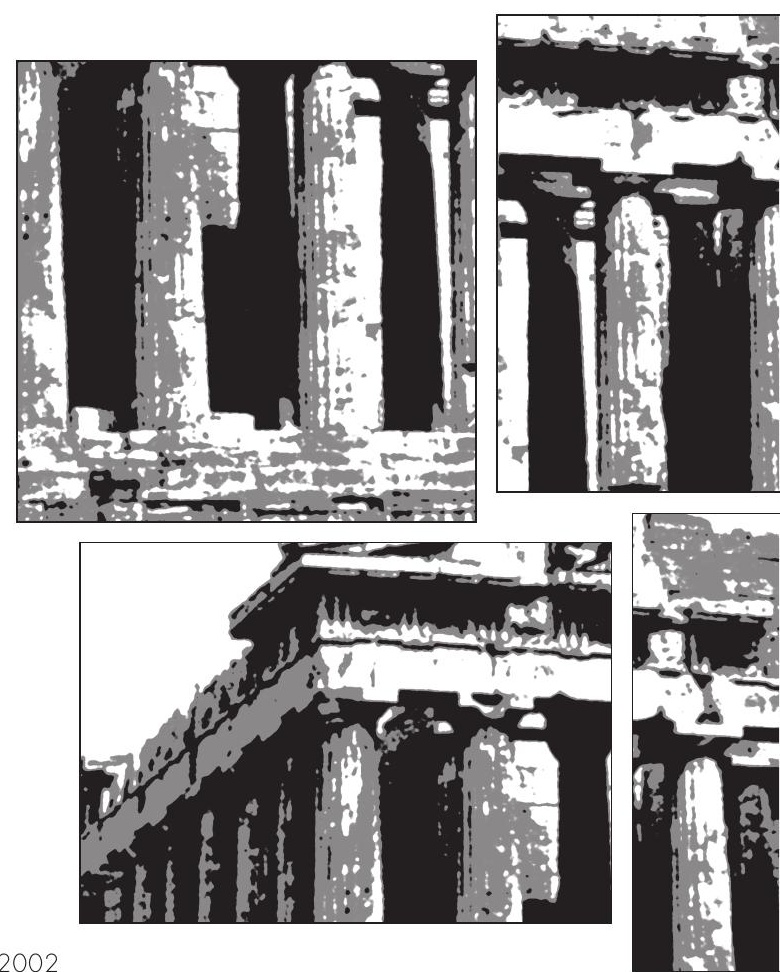


